\title{
The Importance of Club Revenues for Player Salaries and Transfer Expenses-How Does the Coronavirus Outbreak (COVID-19) Impact the English Premier League?
}

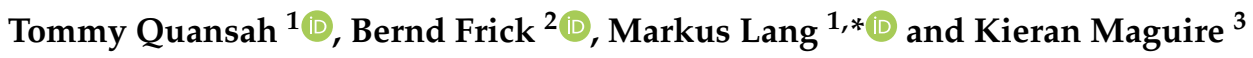 \\ 1 Institute of Sport Sciences, University of Lausanne, Bâtiment Synathlon, 1015 Lausanne, Switzerland; \\ tommy.quansah@unil.ch \\ 2 Department of Management, Paderborn University, Warburger Str. 100, 33098 Paderborn, Germany; \\ bernd.frick@uni-paderborn.de \\ 3 Centre for Sport Business, Management School, University of Liverpool, Liverpool L69 3BX, UK; \\ kieran.maguire@liverpool.ac.uk \\ * Correspondence: markus.lang@unil.ch
}

check for updates

Citation: Quansah, T.; Frick, B.; Lang, M.; Maguire, K. The Importance of Club Revenues for Player Salaries and Transfer Expenses-How Does the Coronavirus Outbreak (COVID-19) Impact the English Premier

League? Sustainability 2021, 13, 5154. https:// doi.org/10.3390/su13095154

\section{Academic Editors:}

Fernando Lera-Lopez,

Themistocles Kokolakakis,

Girish Ramchandani and Marc

A. Rosen

Received: 11 March 2021

Accepted: 29 April 2021

Published: 5 May 2021

Publisher's Note: MDPI stays neutral with regard to jurisdictional claims in published maps and institutional affiliations.

Copyright: (c) 2021 by the authors. Licensee MDPI, Basel, Switzerland. This article is an open access article distributed under the terms and conditions of the Creative Commons Attribution (CC BY) license (https:/ / creativecommons.org/licenses/by/ $4.0 /)$.

\begin{abstract}
The COVID-19 pandemic has caused significant disruption in the sports industry and has raised the question of whether the football industry is based on a sustainable business model. Using data from the English Premier League (EPL), we develop a regression model to achieve two objectives. First, we examine the relationship between the different revenue sources (TV revenues, match revenues, and commercial revenues) and the main cost drivers of professional football clubs (player salaries and transfer expenses). Second, we seek to predict the likely impact of a major market downturn such as the COVID-19 pandemic in the EPL. Our results suggest that TV revenues are by far the most important source of income for player salaries and market values, followed by match revenues and commercial revenues. We predict that player salaries, market values, and transfer expenses will all decrease in the forthcoming EPL season, 2020/2021. The magnitude of the reduction depends on the coronavirus scenario and ranges from $-20.4 \%$ to $-9.5 \%$ for player salaries and $-26.7 \%$ to $-12.4 \%$ for player market values. Our study seeks to explore the relative impact of the three main revenue sources in the EPL on the unprecedented growth of player salaries, market values, and net transfer expenses in the last three decades. In addition, our study adds to the understanding of the pandemic's expected impact on the EPL.
\end{abstract}

Keywords: COVID-19; coronavirus; transfer fees; players market values; Premier League

\section{Introduction}

For many years, transfer fees and player salaries have seen mainly one direction, upwards. Fuelled by increasing match, sponsorship, and broadcasting revenues, particularly in the English Premier League (EPL), worldwide football transfer fees reached a record high of USD7.4B in the year 2019, almost tripling the fees paid in 2012 [1]. The war for talents among football clubs is driven by the desire for on-field success and win maximisation [2,3]. Player salaries, as well as transfer fees, constitute the most important cost factor of clubs in modern professional football [4]. Szymanski [5] has shown a statistically significant and positive impact of clubs' staff expenditures in the form of player salaries and transfer fees on their sporting success.

The coronavirus pandemic (COVID-19), which caught companies worldwide by surprise, has been nothing but a disaster for the sports industry so far and has raised the question of whether the sports industry, in particular the European football industry, is based on a sustainable business model (e.g., [6-8]). While some football leagues such as France, Belgium, and the Netherlands abandoned the 2019/2020 season, other leagues continued without spectators, with significant revenue losses for the clubs in both cases. While several football industry professionals expressed the view that this could lead to 
a contraction of the player market in the near future [9], no academic study has so far investigated the possible effects of the coronavirus epidemic. Our paper sheds light on this issue by examining the likely consequences of COVID-19 for professional football.

Using data from the EPL, we develop an empirical model to achieve two objectives. First, we aim to study the importance of club revenues on player salaries and transfer costs. In particular, we examine how changes in the different income sources of football clubs (TV revenues, match revenues, and commercial revenues) affect player salaries, player market values, and net transfer expenses. Second, we seek to estimate the impact of a major market downturn such as the COVID-19 pandemic in the EPL. In particular, we predict the (likely) development of player salaries, net transfer expenses, and player market values in the forthcoming EPL season in three possible coronavirus scenarios.

The main contribution of our paper is to determine the relative impact of the three main revenue sources in professional football on the unprecedented growth of player salaries, market values, and net transfer expenses in the last three decades. In addition, our study adds to the understanding of the economic impacts of the COVID-19 pandemic on sports. Thus, our study aims at providing new insights to sport management professionals on what to expect for the development of the football labour markets in crises. Our study also serves as a reference point for future research on sports labour markets, and managers of football leagues and clubs.

The remainder of the paper is organised as follows: Section 2 introduces the background with the COVID-19 pandemic and the main variables of our model. Section 3 describes the data and the empirical model. Section 4 presents the results of the empirical investigation and predicts the impact of the COVID-19 pandemic. Section 5 provides a discussion, and the paper concludes with Section 6.

\section{Background}

\subsection{The COVID-19 Pandemic}

The coronavirus disease 2019 (COVID-19) is a highly infectious respiratory illness transmitted through human and animal interaction and caused by the strain of coronavirus, the Severe Acute Respiratory Syndrome Coronavirus 2 (SARS-CoV-2). The first cases were reported in Wuhan, China, in December 2019 and then throughout the world. By February 2020, the virus had reached Italy, where it prompted a high number of infections and deaths, which eventually forced the Italian government to close schools, companies, and borders and to suspend commercial air traffic during February and March 2020. Other European countries experienced, time-delayed, similar developments, with different degrees of government-imposed measures and ordinances to lower infections and casualties.

Like in other countries, the EPL, together with the Football Association, English Football League, the Women's Super League, and Women's Championship collectively suspended professional football in England in March 2021. After a two-month interruption, during which virtually no sporting events took place worldwide (except for the Belarusian league), the German Bundesliga was the first major professional football league to resume in May 2020, under strict control—and without spectators. The EPL followed suit in June 2020, also without stadium audiences.

Despite having developed hygiene concepts to prevent the spread of COVID-19 among stadium visitors, essentially all major sports leagues started the 2020/2021 season without spectators [10-12]. Further, even after the introduction of several vaccines against COVID-19 at the beginning of the year 2021, the majority of sports events have remained closed to the general public due to the relatively low percentages of vaccinated people, increasing new infections as of April 2021, as well as the appearance of mutations, against which current vaccinations are believed to be less effective [13]. So-called immunity passes have been in discussion, which would allow immune spectators to enter the stadiums. However, at the time of writing, such immunity passes do not yet exist, and it has not been established how long an immunisation would last [14]. 


\subsection{Research on the COVID-19 Pandemic and Sports}

Research suggests that mass sports events contribute to the spread of the SARS-CoV-2 strain. Olczak et al. [15], for example, investigated the impact of regular mass outdoor meetings on the spread of a virus by considering football matches in England in February and March 2020 and the spread of COVID-19 into April 2020. They found evidence that mass outdoor events were consistent with more cases and deaths-with approximately six additional COVID-19 cases, two additional COVID-19 deaths, and three additional excess deaths per 100,000 people.

In a similar vein, Ahammer et al. [16] analysed how much National Basketball Association (NBA) and National Hockey League (NHL) games held between March 1 and March 11 have contributed to the community spread of COVID-19 in counties surrounding NBA and NHL venues. They conclude that one additional mass gathering increased the cumulative number of COVID-19 deaths in affected counties by $9 \%$.

While the mid-to-long-term impacts of COVID-19 on sports are still to be assessed, first research studies have investigated the instantaneous impacts of COVID-19 on the health and performance of professional athletes. In a multicenter cross-sectional study of professional athletes with prior COVID-19 infection, Martinez et al. [17], for example, observed only rare cases of athletes having potential cardiac involvement after having been infected with the virus.

Economically, the disease already proved to have massive negative short-term financial impacts on the world of sports, as evidenced by the postponement of the Tokyo Summer Olympic Games 2020 at an alleged cost of USD2.8B [18], the discussions surrounding numerous lower-tier football clubs in Europe threatened by insolvency [19,20], or the loss of sponsors due to coronavirus-caused revenue decreases [21]. Academic research that examines the impact of COVID-19 on sports is flourishing, as evidenced by the special issue of Soccer \& Society [22].

\subsection{Revenue Sources of Football Clubs}

The three main revenue sources of football clubs have traditionally been match income (i.e., ticketing, food and beverage, and parking), media and broadcasting income, as well as commercial income from sponsorship and merchandising [23].

While the loss of match revenues appears to be the most obvious effect that clubs are confronted with due to COVID-19, EPL club revenues are likely to be impacted in further ways.

The re-start of the 2019/2020 season in June 2020 prevented EPL clubs from having to refund $£ 762 \mathrm{M}$ of advance payments to broadcasters, as would have been the case in the event the season was completely cancelled. However, the clubs still face financial ramifications from media houses. A league-wide penalty of $£ 330 \mathrm{M}$ applies as the league had not been able to fulfil its contractual obligations concerning the timing and delivery of matches played in empty stadiums [12].

In an industry report published in May 2020, sports marketing company Two Circles predicted a 37\% year-on-year decrease in Global sports sponsorship rights fees for the year 2020 as a result of the COVID-19 pandemic [24]. While sponsors are likely to receive considerable rebates due to the cancellation or postponement of sporting events, a large part of new sponsorship agreements had been put on hold, while many existing agreements are likely to end as a result of companies implementing cost-cutting measures. Some of the most important industries for sports sponsorships have been hit hard by the pandemic, most notably, the financial services sector, airline carriers, as well as automotive and energy companies [24].

Changes in their income situation are likely to result in changes in the expenditures of the clubs. While most professional teams in Europe are considered to be win rather than profit maximisers, clubs can only spend as much as they receive because they are subject to budget constraints [3]. 


\subsection{Player Salaries}

The war for playing talent among the top European clubs is driven by the desire for on-field success and win maximisation $[2,3,25]$. Player salaries constitute the single largest cost factor of clubs in modern professional football [25]. Wages represent anything between $60 \%$ and $72 \%$ of revenues in each of the five large European football leagues [4] and account for between $70 \%$ and $80 \%$ of total operating costs in the EPL. The previous growth of club revenues in the EPL was accompanied by considerably increasing wage bills.

Apart from the well-documented correlation of club revenues and team wage bills [26], several player-specific variables have been found to impact individual salaries. These variables include measures of performance and talent, such as age, position, number of appearances, and goals scored, as well as popularity. Past performance serves as an indicator of future performance, making an athlete's recent sporting performance and talent relevant for salary negotiations and serves as an important determinant in salary models (e.g., [27-30]). Empirical studies have further observed an inverse U-shaped relationship between age and salary. On-field experience is associated with higher salaries up to a certain point when the salary starts to decline again. In football, players reach their maximum salary between the age of 26 and 28 [27,31]. Additionally, certain players are more popular than others, irrespective of performance or mere talent, which significantly and positively influences their salary [28].

While individual player salaries are typically not disclosed in European football [32], evidence from the North American Major Leagues suggests that salaries in professional sports are generally right-skewed, with a relatively large number of low salaries and a few players earning far more [33]. These large salary differences are often explained by the 'superstar' effects as discussed by Adler [34] and Rosen [35]. Adler [34] explains the emergence of superstars and the resulting skewed income distribution among athletes by network externalities of popularity, whereas Rosen [35] suggests that the supply of talent is fixed, and the distribution of talent is freely observable. As top talent cannot be substituted by less talented players, the demand for over-achievers is particularly high. Thus, relatively small differences in talent at the top of the talent distribution lead to large differences in earnings [33].

\subsection{Net Transfer Expenses}

Transfer fees had been on the rise before the COVID-19 pandemic. In 2019, worldwide football transfer fees reached USD7.4B, compared to USD2.71B in the year 2012 [1]. There had been as many as 39 transfers with fees in excess of USD50m in 2019 alone [1], costs that are to be amortised by the clubs over the length of the player's contract.

From a legal perspective, the "transfer fee is a payment made between clubs in relation to a transfer operation usually including an early termination of a player's contract without just cause, excluding training compensation" [36]. In other words, it is compensation for releasing a player before contract end, which enables the releasing club to offset financial losses incurred from the contractual expiry of its asset. The subject is therefore not the player himself, but the player contract and the releasing club's registration of the player with the member association [37]. The fee can either be negotiated between the releasing and the acquiring club or can be a fixed fee as part of a release clause in the player's existing contract. Contracts in Spain have such a release clause, as Royal Decree $(1006 / 1985)$ explicitly grants athletes the right to terminate their contractual relationship early conditional on the payment of a predetermined compensation [38].

Numerous clubs have developed a distinct business model by focusing on the discovery, development, and subsequent profitable on-sale of players. For some of these clubs, transfer fees have become an indispensable income source. EPL clubs are rather net spenders, buying established players from other leading European and non-European leagues. Net transfer expenses as used here are the sum of transfer fees received and money spent for signing new players. Transfer fees represent discretionary spending in the present market as opposed to wages, which are mandatory in relation to an existing contract. 


\subsection{Player Market Values}

In the sports management literature, there appears to be some ambiguity regarding the concepts of transfer price (or fee) and player market value and their relationship to each other.

Müller et al. [39] describe player market values as estimates of the transfer fees that are most likely to be paid, while Kirschstein and Liebscher [40] describe transfer fees as estimates of player market values. Herm et al. [41] define the market value of a player as an estimate of the amount of money a club is willing to pay to sign that player, ignoring the possibility of money laundry, bribery, and backroom deals that influence this "willingness" and the amount to be offered, which would eventually lead to distorted player market values.

To separate the terms "market value" and "transfer price", it is thus helpful to look at the two concepts in more detail. In analogy to other areas such as marketing or finance, we distinguish between value and price. While no single measure of value has gained universal acceptance [42], finance scholars consider valuation as an assessment of assets based on their intrinsic characteristics, while pricing manifests itself in the form of comparisons across transactions [43]. In contrast to value, the price of an asset is determined in large part by mood and momentum, liquidity, incremental information as well as groupthink [44].

Traditionally, the players' market values have been estimated by the sporting departments of football clubs themselves in anticipation of the transfer fees to be paid or to be received in case a player contract is prematurely terminated [39]. Researchers and service providers usually generate player values by comparing and contrasting individual player characteristics and performances with those of players in recent transactions and the transfer fees realised there. The approaches used do not aim at generating intrinsic value, but at comparing prices in similar transactions. Thus, what is generally referred to as player market value is a "price estimation" rather than a "valuation". Player market values in this sense are subjective, are influenced by the methods and parameters used [43], can be biased [40], and depend on the overall pricing situation on the player market which itself is influenced by supply and demand. The market value of a player is, thus, a theoretical construct. Unlike products and services where the value or the price is associated with a property right, there are no rights associated with a player's market value-in contrast to a player's transfer fee.

One can distinguish between two valuation approaches: data driven and crowd driven. Data-driven approaches are methods that make use of statistical models with an established set of indicators and empirically derived weights to estimate a player's market value [39]. In the case of crowd-driven valuation approaches, registered community members perform their subjective estimations of player market values on dedicated platforms, based on arbitrary indicators and subjective weighting. Using a hierarchical approach with several different indicators such as user evaluations, dedicated judges then assign subjective weightings to all prior estimations after performing a market value estimation themselves [39]. These market values are available at individual and team levels for most professional football leagues in the world and are regularly used by researchers as a proxy for transfer fees (e.g., $[27,28])$, since actual transfers do not happen regularly, and data are not always publicly available. The largest and most well-known crowd-driven valuation platform is the German website transfermarkt.de, established in 2001.

In this paper, we consider the market value of a player as a theoretical construct that aims at approximating the current market price for releasing that player from an existing contract, irrespective of its remaining length or status. The market price of a player is determined by the overall situation on the player market, i.e., supply and demand, the player's performance, his individual characteristics, as well as his popularity. In contrast, a transfer fee is compensation money to offset the financial losses incurred by the releasing club from the contractual expiry of the asset, either as part of an agreement between the releasing and the acquiring club or following the execution of a release clause included in the players' current contract. The two concepts are summarised in Table 1. Despite 
these differences, market values are a good proxy for transfer fees as they are highly correlated $[28,41]$.

Table 1. Market value versus transfer price.

\begin{tabular}{|c|c|c|}
\hline Concept & Market Value & Transfer Price/Fee \\
\hline Subject & $\begin{array}{l}\text { The player as a theoretical construct, } \\
\text { irrespective of contract status. }\end{array}$ & $\begin{array}{l}\text { The player registration with member } \\
\text { association, which ties the player to a club } \\
\text { for the life of his contract. }\end{array}$ \\
\hline Manifestation & $\begin{array}{l}\text { Non-observable, estimated by club } \\
\text { officials, sports journalists, academics, and } \\
\text { service providers. }\end{array}$ & $\begin{array}{l}\text { Negotiated cash-settlement between two } \\
\text { clubs for premature termination of } \\
\text { contract or as pre-defined in player } \\
\text { contract. }\end{array}$ \\
\hline Determinants & $\begin{array}{ll}\text { - } & \text { Overall pricing situation on the } \\
\text { - } & \text { Player market (supply/demand) } \\
\text { - } & \text { Popularity of player } \\
\text { - } & \text { Player characteristics }\end{array}$ & $\begin{array}{l}\text { Market value determinants in addition to } \\
\text { the current contract status and contract } \\
\text { conditions (release clause, duration, free } \\
\text { agency). }\end{array}$ \\
\hline Issues & $\begin{array}{l}\text { - } \quad \text { Have a subjective element } \\
\text { Might be biased depending on } \\
\text { evaluator or model used (club } \\
\text { characteristics, nationality, etc.) }\end{array}$ & $\begin{array}{l}\text { Player market not efficient and fee } \\
\text { depends on club needs, know-how, } \\
\text { negotiation skills, and market power } \\
\text { - Not always publicly available } \\
\text { - } \quad \text { Can be distorted due to money } \\
\text { laundry, corruption, and secret } \\
\text { "deals" } \\
\text { - Conditional fees are often not } \\
\text { displayed }\end{array}$ \\
\hline
\end{tabular}

Source: Own table.

To sum up this section, we added Table 2, which categorises all income and outcome variables of our study.

Table 2. Categorisation of income and outcome.

\begin{tabular}{|c|c|}
\hline & $\begin{array}{l}\text { Club revenues are the sum of income generated from the three main sources: } \\
\text { matchday receipts, broadcasting rights and commercial transactions. Revenues are } \\
\text { recognized in the profit or loss account after applying a five-step test: }\end{array}$ \\
\hline Club revenues & $\begin{array}{l}\text { 1. There must be a contract between the club and the customer } \\
\text { 2. The club has an obligation to the customer } \\
\text { 3. There is an agreed price } \\
\text { 4. The price is allocated to the obligation } \\
\text { 5. Revenue/income is recognized as the club delivers the obligation }\end{array}$ \\
\hline Player salaries & $\begin{array}{l}\text { Player salaries constitute the single largest cost factor of clubs in modern } \\
\text { professional football. Salaries in the model are proxied by the team wage bill, a } \\
\text { club's total personnel expenses, as provided in the income statements of the clubs. }\end{array}$ \\
\hline $\begin{array}{l}\text { Net transfer } \\
\text { expenses }\end{array}$ & $\begin{array}{l}\text { Net transfer expenses are the sum of transfer fees received and money spent for } \\
\text { signing new players. Transfer fees represent discretionary spending in the present } \\
\text { market as opposed to wages which are mandatory in relation to an existing contract. }\end{array}$ \\
\hline Player market values & $\begin{array}{l}\text { Player market values are a theoretical construct that aims at approximating the } \\
\text { current market price for releasing that player from an existing contract, irrespective } \\
\text { of its remaining length or status. The market price of a player is determined by the } \\
\text { overall situation of the player market, i.e., supply and demand, the player's } \\
\text { performance, his individual characteristics, as well as his popularity. }\end{array}$ \\
\hline
\end{tabular}

\section{Data and Empirical Model}

\subsection{Player Market Values}

The data we use to estimate our regression models (see below) come from the 20 clubs playing in the EPL for the 27 seasons between 1992/1993 and 2018/2019, yielding a total of 540 club-season observations. If we had the relevant information for all clubs over the entire period, our number of observations would be 546 because in the seasons 1992/1993 through 1994/1995, the number of clubs in the EPL was 22. Moreover, we did not include 
season 2019/2020 because the financial data of the clubs were not available for this season at the time of writing the article.

Due to promotion and relegation, the number of different clubs over the observed time period is 49 , with some clubs appearing in the dataset only once and others in every single year. Information on club revenues, team wage bills, and net transfer spending were retrieved from the annual reports of the individual clubs. The player market value estimates are available only from the season 2005/2006 onwards and were retrieved from the website "transfermarkt.de". In each season, each of the 20 clubs employed a squad consisting of 20 to 48 players, yielding 10,043 player-season observations for the 15 seasons $2005 / 2006$ to $2019 / 2020$.

\subsection{Empirical Model}

Several fixed-effects models that account for unobserved heterogeneity across the clubs form the basis of our predictions that we will present below. We used STATA 16 for our empirical analysis. The dependent variables we employ here are the team wage bill of the team $i$ in season $j$, the net transfer spending of club $i$ in season $j$, and the average player value of club $i$ in season $j$. The explanatory variables are the clubs' revenues in season $j-1$ (or the components of these revenues, i.e., match income, TV revenues, and commercial income respectively). Thus, we hypothesise:

(1) Team Wage Bill = $\mathrm{f}$ (Total Revenues of Club);

(2) Net Transfer Expenses $=\mathrm{f}$ (Total Revenues of Club);

(3) Squad Market Value $=\mathrm{f}($ Total Revenues of Club).

Our regression model is, therefore, of the following general form:

$$
\begin{gathered}
\ln \left(W B_{i j}\right)=\alpha_{0}+\alpha_{1} \ln \left(C R_{i j-1}\right)+\sum S D+\varepsilon \\
N T E_{i j}=\alpha_{0}+\alpha_{1} C R_{i j-1}+\sum S D+\varepsilon \\
\ln \left(A P V_{i j}\right)=\alpha_{0}+\alpha_{1} \ln \left(C R_{i j-1}\right)+\sum S D+\varepsilon
\end{gathered}
$$

where

$\ln \left(W B_{i j}\right)$ : natural log of wage bill (WB) of club $i$ in season $j$,

$N T E_{i j}$ : net transfer expenses (NTE) of club $i$ in season $j$ (given that net transfer spending includes positive as well as negative values, we cannot use the natural logarithm as negative values are not defined),

$\ln \left(A P V_{i j}\right)$ : natural $\log$ of average player value (APV) of club $i$ in season $j$ to control for differences in squad size,

$\ln \left(C R_{i j-1}\right)$ or $C R_{i j-1}$ : (natural $\log$ of) club revenues (CR) or sources of income, i.e., match income, TV revenues, commercial income of club $i$ in season $j-1$,

$\sum S D$ : vector of season dummies (SD), and

$\varepsilon$ : error term.

The purpose of the regression models is to identify the relative impact of the three revenue sources (match, broadcasting, and commercial revenues) on the unprecedented growth of player salaries, market values, and net transfer expenses in the last three decades. We conjecture that the impact of the three revenue sources will be the same in a boom and in recession period. Thus, we assume that the factors, which contributed positively to the growth of salaries, market values, and net transfer expenses in the recent boom period, will - to the same extent-contribute to a reduction in salaries, market values, and net transfer expenses in the current recession period.

Our econometric analysis is, therefore, a combination of forecasting and prediction. While forecasting uses historical data to extrapolate from past developments into the future, prediction is more judgmental and takes into account changes taking place in the future. Thus, we first estimate a series of regression models using historical data on the development of the EPL clubs' revenues and then derive three different scenarios 
representing the most likely development of club revenues, based on what we know to date with respect to the likely consequences of COVID-19 on the revenue sources of the EPL clubs. Based on the results of the regression analyses and the three forecast scenarios, we then predict the development of player salaries (that account for between $70 \%$ and $90 \%$ of all wage expenses paid by the clubs), net transfer expenses, and average player market values due to COVID-19. Table 3 presents the descriptive statistics for all main variables included in the analysis.

Table 3. Descriptive statistics.

\begin{tabular}{lccccc}
\hline Variables & Obs & Mean & SD & Min & Max \\
\hline Total Club Revenues & 542 & 91.52 & 102.98 & 4.31 & 627.10 \\
Log(Total Club Revenues) & 542 & 3.99 & 1.07 & 1.46 & 6.44 \\
Match Revenues & 542 & 19.80 & 23.80 & 0.00 & 111.64 \\
Log(Match Revenues) & 538 & 2.49 & 0.98 & -0.47 & 4.72 \\
TV Revenues & 542 & 46.22 & 47.59 & 0.00 & 260.79 \\
Log(TV Revenues) & 540 & 3.20 & 1.29 & 0.18 & 5.56 \\
Commercial Revenues & 542 & 25.39 & 41.95 & 0.00 & 276.10 \\
Log(Commercial Revenues) & 540 & 2.49 & 1.19 & -5.26 & 5.62 \\
Net Spending & 542 & 17.17 & 32.52 & -45.33 & 249.67 \\
Wages & 542 & 55.99 & 58.11 & 2.70 & 332.30 \\
Log(Wages) & 542 & 3.50 & 1.11 & 0.99 & 5.81 \\
Average Player Value & 296 & 4.91 & 3.98 & 0.41 & 21.69 \\
Log(Average Player Value) & 296 & 1.32 & 0.74 & -0.89 & 3.08 \\
\hline
\end{tabular}

\section{Results}

4.1. The Impact of Income Sources on Player Salaries, Net Transfer Expenses, and Player Market Values

First, we estimate Model (1) to understand how the three different revenue sources of football clubs influence player salaries. Given that the revenues from the three sources (match, TV, and commercial) are highly correlated at $r>0.80$, we cannot include them in the regression models simultaneously as this leads to multicollinearity.

Since we use the natural logarithm of the variables on both sides of the equation, the coefficients can be interpreted as elasticities. Thus, according to the results displayed in Table 4, a $1 \%$ increase (10\% increase) in total club revenues increases player salaries by $0.728 \%(7.28 \%)$. It also appears from Table 4 that TV revenues are by far the most important revenue source with respect to player salaries, followed by match revenues and commercial revenues.

Table 4. Impact of revenue sources on player salaries in the EPL.

\begin{tabular}{|c|c|c|c|c|}
\hline & $\begin{array}{c}(1) \\
\log (\text { Wages })\end{array}$ & $\begin{array}{c}(2) \\
\log (\text { Wages })\end{array}$ & $\begin{array}{c}(3) \\
\text { Log(Wages) }\end{array}$ & $\begin{array}{c}(4) \\
\text { Log(Wages) }\end{array}$ \\
\hline Log(Total Club Rev.) & $0.728^{* * *}(0.0693)$ & - & - & - \\
\hline Log(Match Rev.) & - & $0.334^{* * *}(0.0844)$ & - & - \\
\hline Log(TV Rev.) & - & - & $0.487^{* * *}(0.120)$ & - \\
\hline Log(Commercial Rev.) & - & - & - & $0.273^{* * *}(0.0781)$ \\
\hline Year Dummies & included & included & included & included \\
\hline Constant & $-0.135(0.156)$ & $1.059^{* * *}(0.124)$ & $1.035^{* * *}(0.137)$ & $1.187^{* * *}(0.100)$ \\
\hline Nof Obs. & 542 & 538 & 540 & 540 \\
\hline$N$ of Teams & 49 & 48 & 48 & 48 \\
\hline Nof Obs. per Team & $1-27$ & $1-27$ & $1-27$ & $1-27$ \\
\hline$R 2$ within & 97.5 & 96.3 & 96.2 & 96.2 \\
\hline R2 between & 95.6 & 92.5 & 86.9 & 87.9 \\
\hline$R 2$ overall & 97.0 & 94.3 & 90.3 & 93.2 \\
\hline
\end{tabular}

When estimating Model (2), we cannot use logs because net transfer expenses (net spending) also include negative values (i.e., clubs earn more from selling players than they spend to sign new players) and the log of negative values is not defined. As a consequence, 
the interpretation of the coefficients in Table 5 is slightly different. Here, each additional British Pound coming from, e.g., TV revenues increases net transfer expenses by 44.3 pence. What is perhaps surprising is that each revenue source seems to have a similar impact on net transfer expenses, because the respective impact of match and commercial revenues is almost identical to that of TV revenues.

Table 5. Impact of revenue sources on net transfer expenses (net spending) in the EPL.

\begin{tabular}{|c|c|c|c|c|}
\hline & $\begin{array}{c}(1) \\
\text { Net Spending }\end{array}$ & $\begin{array}{c}(2) \\
\text { Net Spending }\end{array}$ & $\begin{array}{c}(3) \\
\text { Net Spending }\end{array}$ & $\begin{array}{c}(4) \\
\text { Net Spending }\end{array}$ \\
\hline Total Club Revenues & $0.197^{* * *}(0.0324)$ & - & - & - \\
\hline Match Revenues & - & $0.428^{* * *}(0.138)$ & - & - \\
\hline TV Revenues & - & - & $0.443^{* * *}(0.132)$ & - \\
\hline Commercial Revenues & - & - & - & $0.415^{* * *}(0.0432)$ \\
\hline Year Dummies & included & included & included & included \\
\hline Constant & $-1.013(2.526)$ & $-2.181(3.247)$ & $-0.935(2.723)$ & $-0.367(2.246)$ \\
\hline N of Observations & 542 & 542 & 542 & 542 \\
\hline Nof Teams & 49 & 49 & 49 & 49 \\
\hline Nof Observations per Team & $1-27$ & $1-27$ & $1-27$ & $1-27$ \\
\hline R2 within & 41.7 & 35.6 & 37.2 & 44.8 \\
\hline R2 between & 78.7 & 73.2 & 77.0 & 81.8 \\
\hline$R 2$ overall & 47.1 & 39.0 & 42.6 & 51.2 \\
\hline
\end{tabular}

In the case of player market values (model 3), we again use logs on both sides of the equation. It appears from Table 6 that a $1 \%(10 \%)$ increase in total income is associated with an $0.955 \%(9.55 \%)$ increase in player values. Similar to the results of Model (1), TV revenues are far more important than either match or commercial revenues.

Table 6. Impact of revenue sources on average market values in the EPL.

\begin{tabular}{|c|c|c|c|c|}
\hline & $\begin{array}{c}(1) \\
\text { Log(Average } \\
\text { Player Value) }\end{array}$ & $\begin{array}{c}(2) \\
\text { Log(Average } \\
\text { Player Value) }\end{array}$ & $\begin{array}{c}(3) \\
\text { Log(Average } \\
\text { Player Value) }\end{array}$ & $\begin{array}{c}(4) \\
\text { Log(Average } \\
\text { Player Value) }\end{array}$ \\
\hline Log(Total Club Revenues) & $0.955^{* * *}(0.111)$ & - & - & - \\
\hline Log(Match Revenues) & - & $0.487^{* * *}(0.125)$ & - & - \\
\hline Log(TV Revenues) & - & - & $0.844^{* * *}(0.200)$ & - \\
\hline $\begin{array}{l}\text { Log(Commercial } \\
\text { Revenues) }\end{array}$ & - & - & - & $0.347^{* *}(0.156)$ \\
\hline Year Dummies & included & included & included & included \\
\hline Constant & $\begin{array}{c}-2.973^{* * *} \\
(0.462)\end{array}$ & $-0.397(0.354)$ & $\begin{array}{c}-1.930 * * * \\
(0.685)\end{array}$ & $0.0421(0.410)$ \\
\hline N of Observations & 296 & 296 & 296 & 296 \\
\hline Nof Teams & 39 & 39 & 39 & 39 \\
\hline Nof Observation per Team & $1-15$ & $1-15$ & $1-15$ & $1-15$ \\
\hline$R 2$ within & 68.0 & 62.4 & 64.2 & 60.7 \\
\hline R2 between & 73.4 & 68.4 & 46.0 & 49.9 \\
\hline R2 overall & 80.5 & 74.6 & 59.9 & 68.2 \\
\hline
\end{tabular}

In further analyses (see Tables 7-9), we distinguish the "Big 6" clubs (Arsenal, Chelsea, Tottenham Hotspur, Liverpool FC, Manchester City, and Manchester United) from the other 14 teams, the composition of which changes every year due to promotion and relegation. This split between large clubs and the rest allows us to examine whether the above results change depending on the clubs' market size. 
Table 7. Revenue sources and player salaries in the EPL, by size of club.

\begin{tabular}{|c|c|c|c|c|c|c|c|c|}
\hline $\begin{array}{l}\text { Dep. Variable: } \\
\text { Log(Player Salaries) }\end{array}$ & $\begin{array}{l}(1.1) \\
\text { Big } 6\end{array}$ & $\begin{array}{l}(1.2) \\
\text { Rest }\end{array}$ & $\begin{array}{l}(2.1) \\
\operatorname{Big} 6\end{array}$ & $\begin{array}{l}(2.2) \\
\text { Rest }\end{array}$ & $\begin{array}{l}(3.1) \\
\text { Big } 6\end{array}$ & $\begin{array}{l}(3.2) \\
\text { Rest }\end{array}$ & $\begin{array}{l}(4.1) \\
\text { Big } 6\end{array}$ & $\begin{array}{l}(4.2) \\
\text { Rest }\end{array}$ \\
\hline Log(Total Revenues & $\begin{array}{c}0.753^{* * *} \\
(0.127)\end{array}$ & $\begin{array}{l}0.669^{* * *} \\
(0.0729)\end{array}$ & - & - & - & - & - & - \\
\hline Log(Match Revenues) & - & - & $\begin{array}{c}0.480^{* * *} \\
(0.116)\end{array}$ & $\begin{array}{l}0.235^{* * *} \\
(0.0813)\end{array}$ & - & - & - & - \\
\hline Log(TV Revenues) & - & - & - & - & $\begin{array}{c}0.402 \\
(0.216)\end{array}$ & $\begin{array}{c}0.491^{* * *} \\
(0.0888)\end{array}$ & - & - \\
\hline Log(Commercial Revenues) & - & - & - & - & - & - & $\begin{array}{c}0.248 \\
(0.153)\end{array}$ & $\begin{array}{l}0.310 * * * \\
(0.0661)\end{array}$ \\
\hline Year Dummies & included & included & included & included & included & included & included & included \\
\hline Constant & $\begin{array}{l}-0.213 \\
(0.348)\end{array}$ & $\begin{array}{c}-0.00658 \\
(0.139)\end{array}$ & $\begin{array}{c}0.848^{* *} \\
(0.273)\end{array}$ & $\begin{array}{l}1.124^{* * *} \\
(0.0651)\end{array}$ & $\begin{array}{l}1.419 * * * \\
(0.314)\end{array}$ & $\begin{array}{l}0.920 * * * \\
(0.0721)\end{array}$ & $\begin{array}{l}1.438^{* * *} \\
(0.283)\end{array}$ & $\begin{array}{l}1.071 * * * \\
(0.0624)\end{array}$ \\
\hline$N$ of Observations & 158 & 384 & 158 & 380 & 158 & 382 & 158 & 382 \\
\hline$N$ of Teams & 6 & 43 & 6 & 42 & 6 & 42 & 6 & 42 \\
\hline Observations per Team & $23-27$ & $1-17$ & $23-27$ & $1-27$ & $23-27$ & $1-27$ & $23-27$ & $1-27$ \\
\hline R2 within & 98.7 & 96.8 & 98.0 & 95.7 & 97.0 & 96.2 & 97.0 & 96.0 \\
\hline R2 between & 62.0 & 95.5 & 45.5 & 93.5 & 93.5 & 92.6 & 35.3 & 86.7 \\
\hline R2 overall & 97.5 & 96.3 & 96.4 & 94.7 & 94.7 & 94.0 & 95.1 & 94.5 \\
\hline
\end{tabular}

Standard errors (clustered at team id) in parentheses; ${ }^{*} p<0.10,{ }^{* *} p<0.05,{ }^{* * *} p<0.01$.

Table 8. Revenue sources and net spending in the EPL, by size of club.

\begin{tabular}{|c|c|c|c|c|c|c|c|c|}
\hline $\begin{array}{l}\text { Dep. Variable: } \\
\text { Net Spending }\end{array}$ & $\begin{array}{l}(1.1) \\
\text { Big } 6\end{array}$ & $\begin{array}{l}(1.2) \\
\text { Rest }\end{array}$ & $\begin{array}{l}(2.1) \\
\text { Big } 6\end{array}$ & $\begin{array}{l}(2.2) \\
\text { Rest }\end{array}$ & $\begin{array}{l}(3.1) \\
\text { Big } 6\end{array}$ & $\begin{array}{l}(3.2) \\
\text { Rest }\end{array}$ & $\begin{array}{l}(4.1) \\
\text { Big } 6\end{array}$ & $\begin{array}{l}(4.2) \\
\text { Rest }\end{array}$ \\
\hline Total Revenues & $\begin{array}{l}0.308 * * \\
(0.0865)\end{array}$ & $\begin{array}{l}0.351 * * \\
(0.134)\end{array}$ & - & - & - & - & - & - \\
\hline Match Revenues & - & - & $\begin{array}{c}-0.0314 \\
(0.390)\end{array}$ & $\begin{array}{c}0.687 * * \\
(0.281)\end{array}$ & - & - & - & - \\
\hline TV Revenues & - & - & - & - & $\begin{array}{l}0.0994 \\
(0.299)\end{array}$ & $\begin{array}{l}0.396^{* *} \\
(0.191)\end{array}$ & - & - \\
\hline Commercial Revenues & - & - & - & - & - & - & $\begin{array}{c}0.672 * * * \\
(0.0868)\end{array}$ & $\begin{array}{l}0.877 \text { * } \\
(0.444)\end{array}$ \\
\hline $\begin{array}{l}\text { Year Dummies } \\
\text { Constant }\end{array}$ & $\begin{array}{c}\text { included } \\
-4.154 \\
(6.416)\end{array}$ & $\begin{array}{c}\text { included } \\
-1.549 \\
(1.758)\end{array}$ & $\begin{array}{c}\text { included } \\
0.980 \\
(5.935)\end{array}$ & $\begin{array}{c}\text { included } \\
-1.272 \\
(1.800)\end{array}$ & $\begin{array}{c}\text { included } \\
0.444 \\
(6.823)\end{array}$ & $\begin{array}{c}\text { included } \\
0.0998 \\
(1.464)\end{array}$ & $\begin{array}{c}\text { included } \\
-2.352 \\
(5.475)\end{array}$ & $\begin{array}{c}\text { included } \\
-0.912 \\
(1.899)\end{array}$ \\
\hline Nof Observations & 158 & 384 & 158 & 384 & 158 & 384 & 158 & 384 \\
\hline$N$ of Teams & 6 & 43 & 6 & 43 & 6 & 43 & 6 & 43 \\
\hline Observations per Team & $23-27$ & $1-27$ & $23-27$ & $1-27$ & $23-27$ & $1-27$ & $23-27$ & $1-27$ \\
\hline R2 within & 47.9 & 40.8 & 42.6 & 39.0 & 42.7 & 39.7 & 53.8 & 40.3 \\
\hline R2 between & 16.8 & 83.4 & 29.1 & 86.2 & 77.5 & 87.5 & 44.5 & 79.3 \\
\hline$R 2$ overall & 43.8 & 46.1 & 38.7 & 45.1 & 39.2 & 47.9 & 52.6 & 45.0 \\
\hline
\end{tabular}


Table 9. Revenue sources and average player values in the EPL, by size of club.

\begin{tabular}{|c|c|c|c|c|c|c|c|c|}
\hline $\begin{array}{l}\text { Dep Variable: } \\
\text { Log(Average Player Value) }\end{array}$ & $\begin{array}{l}(1.1) \\
\text { Big } 6\end{array}$ & $\begin{array}{l}(1.2) \\
\text { Rest }\end{array}$ & $\begin{array}{l}(2.1) \\
\text { Big } 6\end{array}$ & $\begin{array}{l}(2.2) \\
\text { Rest }\end{array}$ & $\begin{array}{l}(3.1) \\
\text { Big } 6\end{array}$ & $\begin{array}{l}(3.2) \\
\text { Rest }\end{array}$ & $\begin{array}{l}(4.1) \\
\text { Big } 6\end{array}$ & $\begin{array}{l}(4.2) \\
\text { Rest }\end{array}$ \\
\hline Log(Total Revenues) & $\begin{array}{c}1.053^{* * *} \\
(0.122)\end{array}$ & $\begin{array}{c}1.007 * * * \\
(0.232)\end{array}$ & - & - & - & - & - & - \\
\hline Log(Match Revenues) & - & - & $\begin{array}{c}0.689 * * \\
(0.213)\end{array}$ & $\begin{array}{l}0.654^{* * *} \\
(0.184)\end{array}$ & - & - & - & - \\
\hline Log(TV Revenues) & - & - & - & - & $\begin{array}{l}1.091^{* * *} \\
(0.256)\end{array}$ & $\begin{array}{c}0.625^{* * *} \\
(0.202)\end{array}$ & - & - \\
\hline Log(Commercial Revenues) & - & - & - & - & - & - & $\begin{array}{c}0.560 \\
(0.286)\end{array}$ & $\begin{array}{c}0.336 \\
(0.204)\end{array}$ \\
\hline Year Dummies & included & included & included & included & included & included & included & included \\
\hline Constant & $\begin{array}{l}-3.290 * * * \\
(0.616)\end{array}$ & $\begin{array}{l}-3.243^{* * *} \\
(0.891)\end{array}$ & $\begin{array}{l}-0.804 \\
(0.868)\end{array}$ & $\begin{array}{l}-0.931 * * \\
(0.420)\end{array}$ & $\begin{array}{l}-2.417^{*} \\
(0.986)\end{array}$ & $\begin{array}{l}-1.414^{* *} \\
(0.649)\end{array}$ & $\begin{array}{l}-0.296 \\
(1.020)\end{array}$ & $\begin{array}{l}-0.118 \\
(0.426)\end{array}$ \\
\hline Nof Observations & 90 & 206 & 90 & 206 & 90 & 206 & 90 & 206 \\
\hline Nof Teams & 6 & 33 & 6 & 33 & 6 & 33 & 6 & 33 \\
\hline Observations per Team & 15 & $1-15$ & 15 & $1-15$ & 15 & $1-15$ & 15 & $1-15$ \\
\hline$R 2$ within & 40.8 & 60.5 & 39.9 & 59.2 & 39.7 & 55.6 & 40.3 & 55.7 \\
\hline$R 2$ between & 83.4 & 37.0 & 86.2 & 40.7 & 87.5 & 19.5 & 79.3 & 34.3 \\
\hline$R 2$ overall & 46.1 & 51.1 & 45.1 & 50.5 & 47.9 & 33.4 & 45.0 & 41.9 \\
\hline
\end{tabular}

Standard errors (clustered at team id) in parentheses; ${ }^{*} p<0.10,{ }^{* *} p<0.05,{ }^{* * *} p<0.01$.

Regarding player salaries, we find that a decrease in total club revenues leads to a larger reduction in salaries for the Big 6 clubs than for the other 14 teams (see Table 7), suggesting that player salaries at large clubs respond more to changes in club revenues than at small clubs. In addition, a change in match revenues impacts player salaries at the Big 6 clubs more than the salaries at the remaining 14 teams.

Interestingly, in contrast to player salaries, the results from Table 8 indicate that large clubs are expected to adjust their net transfer expenses less than small clubs due to a change in club revenues. Finally, there is no significant difference between large and small clubs regarding the impact of changes in club revenues on average player values (see Table 9).

\subsection{The Impact of the COVID-19 Pandemic}

We proceed in two steps. First, we derive three possible coronavirus scenarios and calculate the COVID-19-induced impact on the three revenue sources (match revenues, TV revenues, and commercial revenues) in each scenario. Second, we predict the impact of the COVID-19 pandemic-induced revenue losses on player salaries, transfer expenses, and player market values in the three coronavirus scenarios based on the regression coefficients obtained from our empirical models.

\subsubsection{Coronavirus Scenarios}

We outline three possible scenarios for the economic development of EPL clubs in the post-COVID-19 era. The scenarios distinguish the three revenue sources and are summarised in Table 10. 
Table 10. Possible COVID-19 scenarios.

\begin{tabular}{|c|c|c|c|c|c|c|c|c|}
\hline in $€ \mathrm{~m}$ & \multicolumn{2}{|c|}{ EPL Club Revenues } & \multicolumn{3}{|c|}{ Covid-Scenarios EPL } & \multicolumn{3}{|c|}{ Covid-Scenarios (in \%) } \\
\hline Total & Total & Average & Worst & Medium & Best & Worst & Medium & Best \\
\hline Matchday & 679.7 & 34.0 & 0.0 & 10.2 & 17.0 & $-100 \%$ & $-70 \%$ & $-50 \%$ \\
\hline Commercial & 1456.6 & 72.8 & 43.7 & 58.3 & 65.5 & $-40 \%$ & $-20 \%$ & $-10 \%$ \\
\hline Broadcast & 3032.6 & 151.6 & 143.4 & 143.4 & 143.4 & $-5 \%$ & $-5 \%$ & $-5 \%$ \\
\hline Total & 5169.0 & 258.5 & 187.1 & 211.8 & 225.9 & $-28 \%$ & $-18 \%$ & $-13 \%$ \\
\hline in $£ \mathrm{~m}$ & \multicolumn{2}{|c|}{ Big-6 Club Revenues } & \multicolumn{3}{|c|}{ Covid-Scenarios Big-6 } & \multicolumn{3}{|c|}{ Covid-Scenarios (in \%) } \\
\hline & Total & Average & Worst & Medium & Best & Worst & Medium & Best \\
\hline Matchday & 494.5 & 82.4 & 0.0 & 24.7 & 41.2 & $-100 \%$ & $-70 \%$ & $-50 \%$ \\
\hline Commercial & 1141.5 & 190.3 & 114.2 & 152.2 & 171.2 & $-40 \%$ & $-20 \%$ & $-10 \%$ \\
\hline Broadcast & 1362.3 & 227.1 & 218.8 & 218.8 & 218.8 & $-4 \%$ & $-4 \%$ & $-4 \%$ \\
\hline Total & 2998.3 & 499.7 & 333.0 & 395.7 & 431.2 & $-33 \%$ & $-21 \%$ & $-14 \%$ \\
\hline \multirow[t]{2}{*}{ in $€ \mathrm{~m}$} & \multicolumn{2}{|c|}{ Other-14 Club Revenues } & \multicolumn{3}{|c|}{ Covid-Scenarios Other-14 Clubs } & \multicolumn{3}{|c|}{ Covid-Scenarios (in \%) } \\
\hline & Total & Average & Worst & Medium & Best & Worst & Medium & Best \\
\hline Matchday & 185.2 & 13.2 & 0.0 & 4.0 & 6.6 & $-100 \%$ & $-70 \%$ & $-50 \%$ \\
\hline Commercial & 315.1 & 22.5 & 13.5 & 18.0 & 20.3 & $-40 \%$ & $-20 \%$ & $-10 \%$ \\
\hline Broadcast & 1670.3 & 119.3 & 111.1 & 111.1 & 111.1 & $-7 \%$ & $-7 \%$ & $-7 \%$ \\
\hline Total & 2170.7 & 155.1 & 124.6 & 133.0 & 137.9 & $-20 \%$ & $-14 \%$ & $-11 \%$ \\
\hline
\end{tabular}

\section{Scenarios}

Worst

No spectators allowed for the upcoming seasons, negative impact on commercial income of $40 \%$, $£ 330 \mathrm{~m}$ of broadcast penalties spread over 2 seasons

Medium

$30 \%$ spectators allowed back to stadium, negative impact on commercial income of $20 \%, £ 330 \mathrm{~m}$ of broadcast penalties spread over 2 seasons

Best $50 \%$ spectators allowed back to stadium, negative impact on commercial income of $10 \%, £ 330 \mathrm{~m}$ of broadcast penalties spread over 2 seasons

TV revenues: The EPL signed its latest broadcasting agreement in 2019 for the three seasons up to 2022, which, together with the broadcasting proceeds from UEFA club competitions, guaranteed an average amount of $£ 152 \mathrm{M}$ per club for 2019. This represented $59 \%$ of total revenues per club. While numerous media experts expect lower income from broadcasting in the future [45], this possible reduction will not come before the new broadcasting agreement is signed, which is post-2022. We, therefore, assume the reduction to be in line with the penalty payment of $£ 330 \mathrm{M}$ for the postponed games in the $2019 / 2020$ season in all three scenarios, which translates into a decrease of $5.4 \%$ for the two successive seasons.

Commercial revenues: Interviews with industry experts confirmed the predictions made by sports marketing company Two Circles expecting a 37\% year-on-year decrease in global sports sponsorship rights fees as a result of the COVID-19 pandemic. According to one expert, sponsorship prices in the EPL were down by 30\% to $40 \%$ by August 2020, while several front-of-shirt sponsorships were still available for Championship clubs shortly before the start of the season, which was unprecedented according to that source. In our worst-case scenario, we thus assume a $40 \%$ decrease in commercial revenues, while our average-case scenario assumes a $20 \%$ decrease. In the best case, premium sports sponsorship opportunities will recover quickly, leading to a reduction in commercial revenues of only $10 \%$.

Match revenues: During the 2018/2019 season, EPL clubs enjoyed an average capacity utilisation of $96 \%$ (worldfootball.net, accessed on 20 August 2020), and match revenues contributed $13 \%$ to the total revenues of the average EPL club. While the EPL did not communicate its plans for spectator admissions at the start of the season 2020/2021, the Deutsche Fussball Liga (DFL), which served as a trailblazer among sports leagues in terms of measures and actions in times of COVID-19, released a hygiene concept to prevent the spread of the virus among stadium visitors for the German Bundesliga. This concept 
contained three scenarios, including different numbers of visitors to be allowed in each stadium. In the case of a high pandemic level, with $\geq 35$ new infections per week per 100,000 inhabitants, no spectators were to be allowed in the stadium. When the pandemic level was medium, with $\geq 5$ and $<35$ new infections per week per 100,000 inhabitants, the concrete number of fans allowed in the stadium was to be defined. In the case of $<5$ new infections per week per 100,000 inhabitants, a successive return to normal operations was planned, depending on agreements between the clubs and the respective local health authorities. In any case, according to the concept, not more than $30 \%$ to $50 \%$ of the stadium capacity was planned to be used. In terms of match revenues, this means that in the worstcase scenario, we assumed no match revenues at all since no spectators will be allowed in the stadium. In the average-case scenario, we assume a reduction in match revenues of $70 \%$; and in the best-case scenario, a decrease of $50 \%$.

\subsubsection{Predicting the Impact of the COVID-19 Pandemic}

To predict the impact of the COVID-19 pandemic, we assume that the correlations between revenues and expenses from Section 4.1, determined for a phase of uninterrupted growth, will also be observed in the opposite direction in a recession period when club revenues decline.

The rationale for this assumption can be justified by one of the economic peculiarities of professional team sports, which is the associative character of competition. No team can improve its position in the standings without worsening the position of at least one other team. If sportive and economic success are correlated, which they usually are, this rank order contest can lead to a rat race which induces clubs to overinvest in playing talent and may result in a ruinous competitive interaction between clubs [46]. It is well known in contest theory of professional team sports $[47,48]$ that club revenues crucially impact this rat race: higher (lower) revenues induce clubs to increase (decrease) their investments in playing talent and thus lead to higher (lower) player salaries and higher (lower) transfer expenses [49].

Anecdotal evidence seems to confirm our assumption that clubs react swiftly with a reduction in player salaries to an exogenous shock such as the insolvency of the Kirch group in 2002 that triggered a significant revenue decline for the German Bundesliga clubs [50]. After the Kirch group went insolvent in 2002, the 36 first- and second-division teams in the German Bundesliga received approximately $€ 270$ million less in TV revenues than expected in the three seasons from 2001-2002 to 2003-2004. Clubs reacted swiftly to this reduction in revenues because average player salaries per club went down from $€ 28.7$ million in 2001-2002 to less than €26 million in 2004-2005 [50].

Based on the above assumption and the regression coefficients from our empirical model, we conclude that a drop in total revenue of $10 \%$ will lead to a decrease in player salaries of $7.28 \%$ (based on Model 1) and a loss of player market values of $9.55 \%$ (based on Model 3). In addition, a drop in total revenue of $£ 1$ results in a reduction in net transfer expenses by 19.7 pence (based on Model 2).

Next, we illustrate the expected impact of COVID-19 on club revenues in the three scenarios in Figure 1, which displays: (i) the pre-pandemic evolution of the different revenue sources (black lines) from season 1992/1993 up to season 2018/2019 and (ii) the expected impact of the COVID-19 pandemic on the different revenue sources for the three coronavirus scenarios (coloured lines and small table). 
160

140

120

\begin{tabular}{|l|c|c|c|}
\hline & Worst case & Medium case & Best case \\
\hline Matchday Revenues & $£-37.1 \mathrm{M}$ & $£-25.9 \mathrm{M}$ & $£-18.5 \mathrm{M}$ \\
\hline TV Revenues & $£-7.8 \mathrm{M}$ & $£-7.8 \mathrm{M}$ & $£-7.8 \mathrm{M}$ \\
\hline Commercial Revenues & $£-32.1 \mathrm{M}$ & $£-16.1 \mathrm{M}$ & $£-8.0 \mathrm{M}$ \\
\hline
\end{tabular}

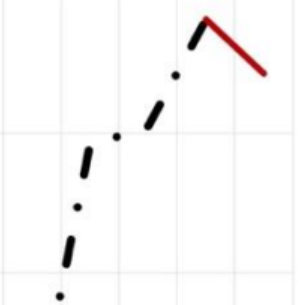

$\begin{array}{lllllllllllll}2008 & 2009 & 2010 & 2011 & 2012 & 2013 & 2014 & 2015 & 2016 & 2017 & 2018 & 2019 & 2021\end{array}$

TV Revenues •.. Matchday Revenues $\longrightarrow$ Commercial Revenues

Figure 1. Revenues by source in the English Premier League and expected impact of COVID-19.

The figure shows that the football clubs of the English Premier League have experienced strong positive growth in terms of broadcasting revenues (dashed line) and commercial revenues (solid line), and more conservative growth in terms of match revenues (dotted line) since the inaugural season 1992 until 2019.

The COVID-19 pandemic is the first shock at a bigger scale for this relatively young league. We predict that the COVID-19 pandemic will have a negative impact on all three revenue sources in all scenarios as shown in the small table of Figure 1. We expect match revenues to experience the strongest decline. Here, our model predicts a reduction of $£ 18.5 \mathrm{M}$ (best case), £25.9 M (medium case) up to £37.1 M (worst case). TV revenues are expected to decrease by $£ 7.8 \mathrm{M}$ in all three scenarios, while commercial revenues might drop between $£ 8.0 \mathrm{M}$ (best case) and $£ 32.1 \mathrm{M}$ (worst case).

Figure 1 also graphically illustrates the revenue drop in all three scenarios by the coloured lines: red displays the worst-case scenario, orange the medium-case scenario, and green the best-case scenario. The COVID-19-induced reductions in all three revenue sources are clearly visible. Note that TV revenues are expected to drop similarly in all three scenarios, so we only display the red line.

Based on the above calculations and the results from our regression models, we are now able to calculate the COVID-19-induced impact on salaries, net transfer expenses, and player market values for the forthcoming EPL season, 2020/2021. The results are presented in Figure 2, which displays: (i) the pre-pandemic development of player salaries (solid line), net transfer expenses (dotted line), and player market values (dashed line) for the seasons 1992/1993 up to 2018/2019 and (ii) the expected impact of the COVID-19 pandemic on the different variables for the three coronavirus scenarios (coloured lines and small table). 


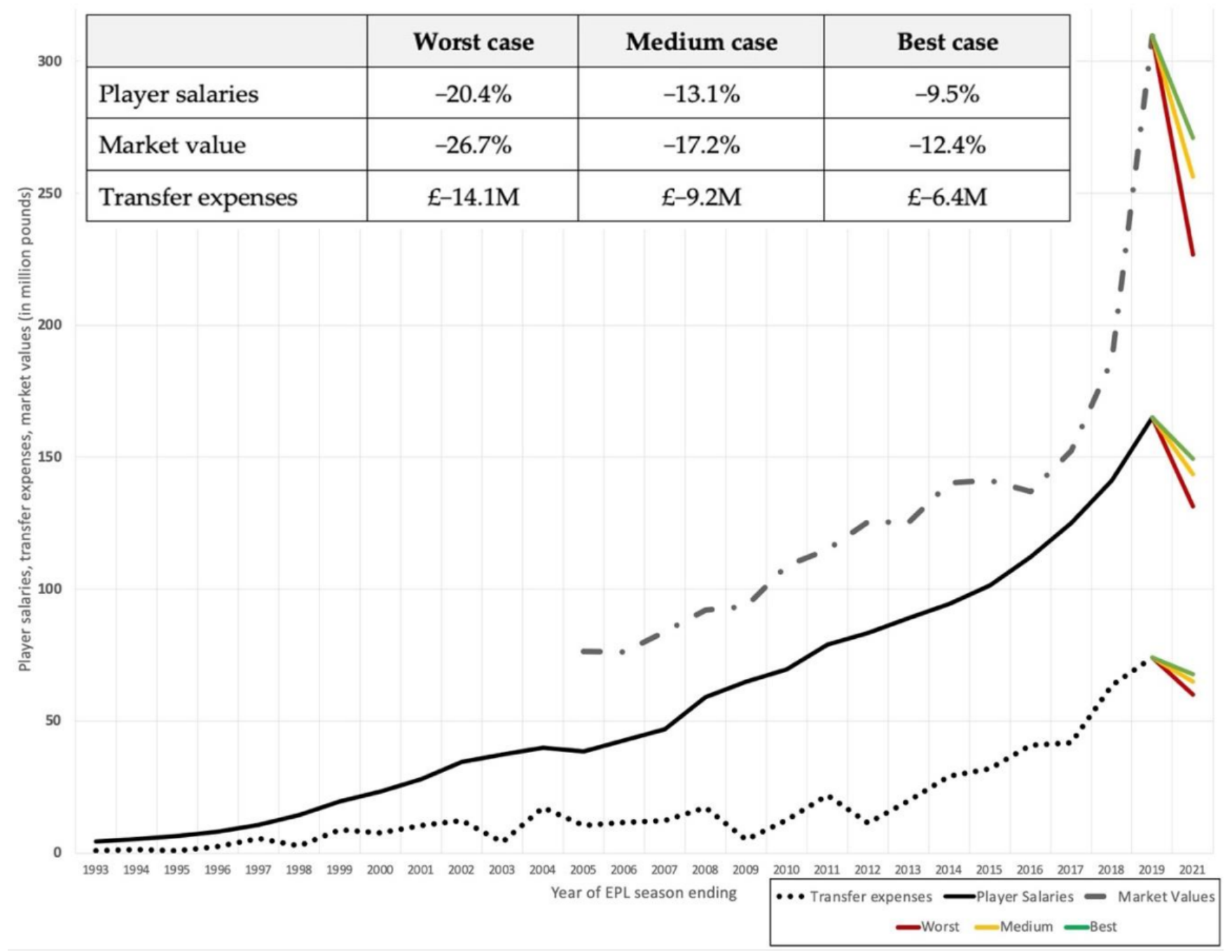

Figure 2. Player salaries, net transfer expenses, and player market values in the English Premier League and expected impact of COVID-19.

The figure shows that player salaries and player market values have experienced a strong positive growth until 2019, while net transfer expenses have been relatively stable until 2013 and then accelerated their growth rate until 2019.

Our model predicts a significant drop in all three variables (compare small table and coloured lines): player market values are expected to experience the largest drop: $-26.7 \%$ in the worst case (red line), $-17.2 \%$ in the medium case (orange line), and $-12.4 \%$ in the best case (green line) scenario. Net transfer expenses and player salaries follow a similar pattern. Remember that the impact on net transfer expenses is calculated in absolute values since we cannot use logs to estimate the model.

Moreover, as derived in Section 4.1, we expect the reduction in player salaries to be stronger for the Big 6 clubs compared to the other 14 teams. The opposite is true for net transfer expenses. Here, we expect a larger drop for the other 14 teams compared to the Big 6 clubs.

Finally, we examine the development of player salaries as a percentage of club revenues to demonstrate how the COVID-19 pandemic affects this relationship. Figure 3 plots the wage/revenue ratio (solid line) for the season 1992/1993 up to 2018/2019. The coloured lines illustrate the different coronavirus scenarios: red displays the worst-case scenario, orange the medium-case scenario, and green the best-case scenario. 


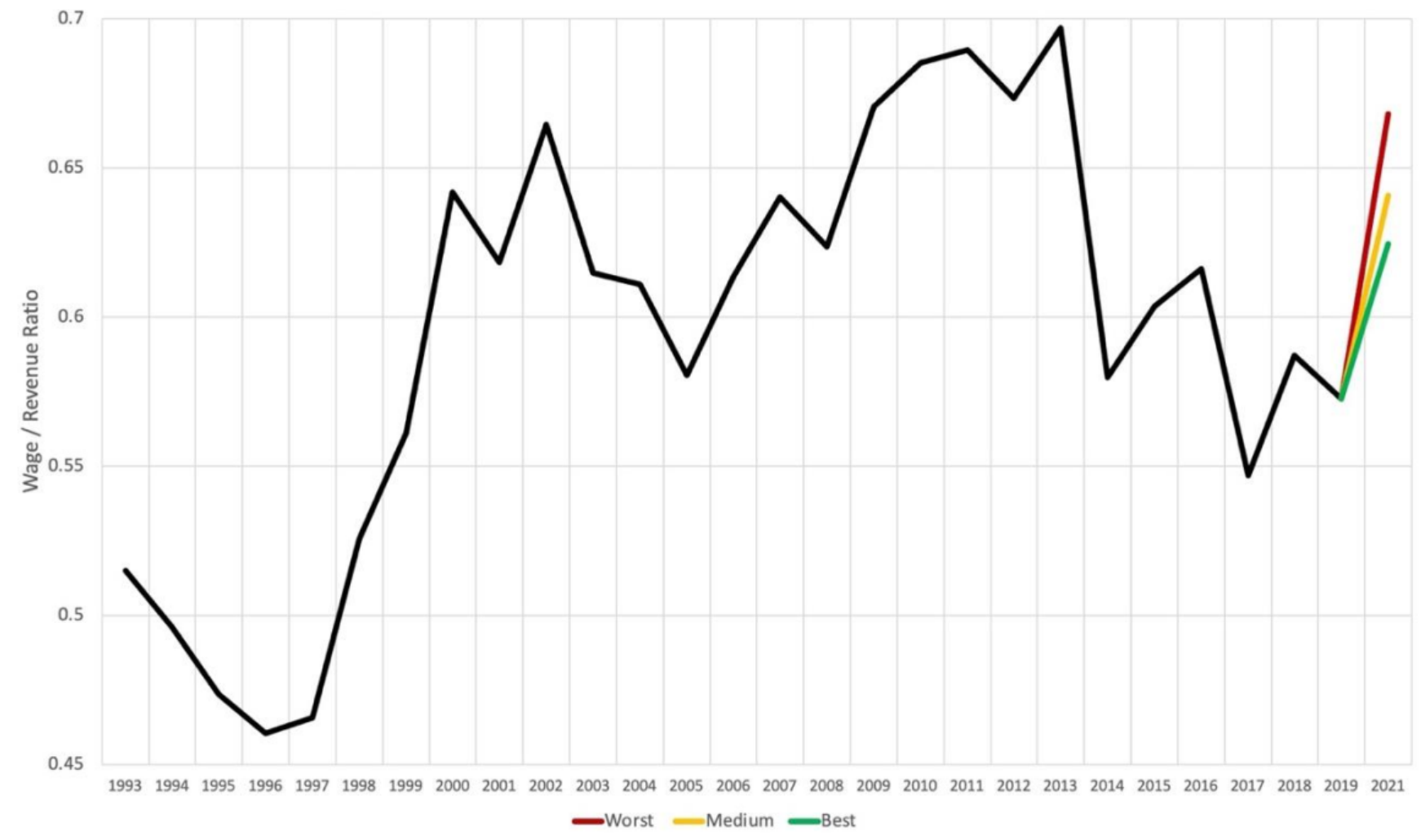

Figure 3. Wage/revenue ratio in the English Premier League and expected impact of COVID-19.

The figure shows that the wage/revenue ratio oscillates considerably over time before the COVID-19 outbreak: the ratio reaches its minimum of 0.46 in the season 1994/1995 and its maximum of 0.69 in the season 2012/2013. Our model predicts that total club revenues are expected to drop more than player salaries due to the COVID-19 pandemic in all three scenarios. As a consequence, the wage/revenue ratio is expected to increase in all three scenarios as shown by the red, orange, and green lines.

To check the robustness of our prediction model, we estimated our main models (the results of which are displayed in Tables 3-5) using a restricted dataset covering the seasons 1992/1993 to 2013/2014 only (our "testing period"). Using the coefficients obtained for the testing period to predict player salaries, net spending, and player market values for the seasons $2014 / 2015$ to $2017 / 2019$, we find that the difference between the predicted and the observed values is very small in all three cases, suggesting that our prediction model does a very good job. The results of the additional estimations are available from the authors upon request.

\section{Discussion}

What is commonly referred to as the peculiarities of the sports industry describes a set of characteristics that distinguishes the sports industry from conventional industries. These peculiarities are as follows: (i) constant industry output, (ii) competitors are needed to produce an output, (iii) a league is naturally a monopoly, and (iv) output quality increases with the quality of the competitors [51,52].

Another point that distinguishes professional football from other industries is that clubs have not been profitable for most of their history [53]. A total of 18 out of 20 football clubs of the English Premier League published their financial accounts for the 2018/2019 season in March 2020, immediately before the COVID-19 outbreak. In defiance of having achieved the 20th consecutive record revenue high in a row, 16 out of these 18 clubs posted net income losses. While companies in most industries seek to maximise profits and are thus able to build up financial reserves, European football is often considered a winmaximisation industry, where additional revenue is used to acquire playing talent $[2,3,25]$ 
to maintain competitiveness in the rat race of winning titles and avoiding relegation. In football clubs, the by far largest part of their operating costs are player salaries, which regularly account for between $60 \%$ and $72 \%$ of revenues in each of the five large European football leagues [4], and account for between $70 \%$ and $80 \%$ of total operating costs in the EPL.

Against this background, the COVID-19 pandemic has raised the question of whether the football industry is based on a sustainable business model (e.g., [6-8]), or whether the modus operandi needs to change to be sustainable and to prevent bankruptcies of clubs in the event of external shocks such as the current COVID-19 pandemic.

Thus, one of the key contributions of our paper is to examine the relationship between the different revenue sources and the main cost drivers of professional football clubs. In particular, we show how changes in the different income sources of football clubs (TV revenues, match revenues, and commercial revenues) affect player salaries, player market values, and net transfer expenses. Our results suggest that TV revenues are by far the most important source of income for player salaries and market values, followed by match revenues and commercial revenues. Not surprisingly, each revenue source seems to have a similar impact on net transfer expenses.

Based on our regression estimations, we estimate the expected impact on the three revenue sources of EPL clubs and predict their impact on player salaries, market values, and transfer expenses in three possible coronavirus scenarios. We conjecture that the COVID-19-induced negative effects on EPL club revenues will translate into reductions in team wage bills, squad market values, and net transfer expenses. In particular, we expect total club revenues to decrease by $28 \%$ (worst case), $18 \%$ (medium case), and $13 \%$ (best case) in the forthcoming EPL season, 2020/2021.

Match revenues will most likely suffer the most (in the worst-case scenario they will be zero), while TV revenues are the least affected of the three revenue sources (only $-5 \%$ ). Our empirical model suggests that player salaries, market values, and transfer expenses will all decrease in the forthcoming season. The magnitude of the reduction depends on the scenario and ranges from $-20.4 \%$ to $-9.5 \%$ for player salaries, from $-26.7 \%$ to $-12.4 \%$ for player market values, and from $£-14.1 \mathrm{M}$ to $£-6.4 \mathrm{M}$ for transfer expenses. Thus, with an average annual salary for an EPL player of approximately $£ 4 \mathrm{M}$, this means a loss of salary of $£ 400,000$ (best case) or $£ 800,000$ (worst case) per year. The traditionally negative transfer balances of most English clubs, on the other hand, will fall from an average of $£ 74.1 \mathrm{M}$ to $£ 60.1 \mathrm{M}$ (worst case) or $£ 67.7 \mathrm{M}$ (best case).

When splitting the sample into the Big 6 clubs and the remaining 14 teams, our model predicts that player salaries will decline more in the Big 6 clubs than in the other 14 teams, while the opposite is true for net transfer expenses. Player market values are expected to decrease equally across all 20 clubs.

In sum, while the impact will be economically relevant for each of these variables (player salaries, market values, and transfer expenses), their impact will remain rather small from a historical perspective. Even in the worst-case scenario, team wage bills, squad market values, and net transfer expenses only decline to the level in the 2017/2018 season. Nevertheless, if the coronavirus pandemic is going to last for a longer period of time and football clubs continue the current modus operandi, their business model is likely to fail, and bankruptcies of clubs can be expected.

One might argue that already the committed "costs" in terms of player salaries written down in long-term contracts prior to the coronavirus pandemic cannot be easily reduced when club revenues decline as a consequence of the crisis. However, the average contract length is approximately 2.3 years [54], which means that more than $40 \%$ of all player contracts are renegotiated every year. This gives clubs ample possibility to lower their wage bill, apart from the voluntary salary cuts that have happened due to the coronavirus pandemic-induced reduction in club revenues [55]. 
Thus, those clubs that have player contracts with longer contract durations, are less flexible to renegotiate player salaries downwards in contracting markets, such as witnessed in the current COVID-19 crises.

In contrast to the other Big 5 European football leagues, where most players agreed to voluntary pay cuts, the majority of EPL players refused to accept any salary reductions in light of COVID-19 [56]. With average remaining contract lengths between 1.5 years (Crystal Palace) and 3.2 years (Tottenham Hotspur) [57], it is, however, only a matter of time until lower player salaries will be observed across EPL teams too. Moreover, new player contracts are likely to include clauses allowing clubs to cut wages in the case of another pandemic or similar events leading to a lockout of fans.

The discussion of the pros and cons of salary caps, which are common practice in North American Major League sports (e.g., [58,59]), have gained new momentum in light of the financial consequences of COVID-19 for football clubs. For a long time, legal specialists questioned whether salary caps are consistent with national and European anti-trust regulations. However, recent expertise by the Scientific Services of the German Parliament concludes that salary caps are compatible with national and European law if introduced and monitored by UEFA [60].

According to media reports, UEFA is currently indeed assessing the possibility of introducing salary caps on a European level [61]. Meanwhile, the English Football League has been a first mover and introduced salary caps for English third- and fourth-tier football in August 2020, with salary caps at $£ 2.5 \mathrm{M}$ and $£ 1.5 \mathrm{M}$ per annum, respectively [62]. However, an arbitration panel ruled in February 2021, that the cap must be withdrawn after the Professional Footballers' Association argued it was "unlawful and unenforceable" [63].

The question remains whether salary caps can prevent those clubs that are willing to spend more than allowed, to do so in the absence of rigorous monitoring to detect and sanction violations [64]. Monitoring the sources of players' ancillary remuneration requires far more effort than monitoring possible "creative accounting" by clubs violating UEFA's Financial Fairplay regulations.

\section{Conclusions}

All countries worldwide are affected by the coronavirus and most sports events have been postponed or cancelled. The year 2020 was supposed to be an important sports year, with major events such as the UEFA Euro 2020 and the Summer Olympics in Tokyo. Both events have been postponed to 2021, causing significant financial as well as political disturbances.

The economic consequences of the COVID-19 pandemic on the sports industry in general, and on European football in particular, are still underexplored. Our paper sheds light on the pandemic's expected impact on professional football. Using data from the English Premier League (EPL), we develop a regression model to achieve two objectives. First, we examine the relationship between the different revenue sources (TV revenues, match revenues, and commercial revenues) and the main cost drivers of professional football clubs (player salaries and transfer expenses). Second, we seek to predict the likely impact of a major market downturn such as the COVID-19 pandemic in the EPL.

Our study shows that salaries, transfer fees, and market values are linked to the level of club revenues and adjust to emerging market conditions. However, market contractions lead to short-term losses, as clubs cannot make fast expenditure adjustment due to longerterm contracts and obligations and because they-driven by the rat race-do not build up reserves under favourable market conditions. As a result, clubs are reliant on external funding sources in unfavourable situations and the current model cannot be considered self-sustainable. However, as football clubs are in many cases treated as Trophy Assets, there might often be external funding possibilities.

Admittedly, our assumptions as well as the available data have influenced the results presented above in a particular way. First, while the coefficient of determination between club revenues on the one hand, and salaries (0.97), as well as market values (0.80), is high, 
club revenues explain only approximately $47 \%$ of the variation in net transfer expenses, indicating the possible existence of other influencing factors. Future research with an emphasis on complementing these factors would be beneficial. Second, apart from the categorisation of clubs into the Big 6 and the other 14, a comparative classification of club owner strategies would, in this respect, offer a good approach for further refining the analysis because differences in owner strategies are likely to translate into differences in spending behaviour-be it in wages or transfer fees. Third, because the future is inherently uncertain, all predictions into the future need to cope with uncertainties $[65,66]$ and may already be outdated soon afterwards, as the most recent developments regarding the European Super League as well as the reform of the UEFA Champions League drastically show. The scenario analysis is a means of developing possible futures to deal with this uncertainty [67]. The focus is thus not to look into the most likely development but to consider different possible developments under key assumptions, i.e., 'What happens if ... '? [68]. We have thus specifically looked for each of the variables on how they could develop in each of the three cases and deduce the consequences according to our model. Our approach to predicting the revenue paths of EPL clubs post-COVID-19 may serve critics to develop their own (more realistic?) perspective and to come up with figures that are different from the ones that we have presented here.

However, the most recent developments clearly support our scenario approach. On 8 March 2021, the German Football Association reported that the match revenues of the 18 first division clubs had decreased by more than $30 \%$ and transfer expenses by $12 \%$ in the season 2019/2020 compared to the season before. Thus, since approximately threequarters of that last season were still played in full stadiums, our best-case projections for the EPL are virtually identical with what actually happened to match revenues and transfer expenses in the Bundesliga in the last season already. This, in turn, suggests that the product, as well as the labour market, reacts very quickly in the expected duration.

Future research may replicate this study with data from other leagues where club financials are accessible, such as the French Ligue 1/2 or the English Championship. The economic consequences and implications of the COVID-19 pandemic remain a fertile and important line of inquiry for sport management scholars.

Author Contributions: Conceptualisation, T.Q., B.F., M.L., and K.M.; methodology, B.F., T.Q., and M.L.; formal analysis, B.F.; data curation, K.M. and T.Q.; writing-original draft preparation, T.Q., M.L., and B.F.; writing-review and editing, T.Q., M.L., and B.F. All authors have read and agreed to the published version of the manuscript.

Funding: This research received no external funding.

Institutional Review Board Statement: Not applicable.

Informed Consent Statement: Not applicable.

Data Availability Statement: Data are not publicly available, though the data may be made available on request from the corresponding author.

Acknowledgments: We wish to acknowledge useful comments and suggestions by six anonymous referees and the editor of the special issue.

Conflicts of Interest: The authors declare no conflict of interest.

\section{References}

1. FIFA-TMS. Global Transfer Market Report 2019: Men's Football. A review of International Football Transfers Worldwide. Available online: https:/ / resources.fifa.com/image/upload/global-transfer-market-report-2019-men.pdf?cloudid=x2wrqjstwjoailnncnod (accessed on 10 April 2021).

2. Garcia-del-Barrio, P.; Szymanski, S. Goal! Profit maximization versus win maximization in soccer. Rev. Ind. Organ. 2009, 34, 45-68. [CrossRef]

3. Késenne, S. The win maximization model reconsidered: Flexible talent supply and efficiency wages. J. Sports Econ. 2006, 7, 416-427. [CrossRef] 
4. Deloitte. Home Truths: Annual Review of Football Finance. 2020. Available online: https://www2.deloitte.com/uk/en/pages/ sports-business-group/articles/annual-review-of-football-finance.html (accessed on 12 October 2020).

5. Szymanski, S. Wages, transfers and the variation of team performance in the English Premier League. In The Econometrics of Sport; Edward Elgar Publishing: Cheltenham, UK, 2013.

6. ECA. ECA Members reflect on COVID-19 Impacts and Football's Sustainable Future. Available online: https://www.ecaeurope. $\mathrm{com} /$ news/eca-members-reflect-on-covid-19-impacts-and-football-s-sustainable-future (accessed on 10 February 2021).

7. LawinSport. Coronavirus and Its Impact on Football-A Sports Law and Policy Centre and Law. Available online: https: / / www.lawinsport.com/topics/covid19-impact/item/coronavirus-a-and-its-impact-on-football-a-sports-law-andpolicy-centre-and-lawinsport-joint-survey (accessed on 10 February 2021).

8. BBC. Coronavirus Pandemic 'Shone Light on Unfair Pay' in Football, Says DCMS Committee Report. Available online: https: / / www.bbc.com/sport/53496696 (accessed on 10 February 2021).

9. Panja. Germany Prepares for Soccer's Return. Available online: https://www.nytimes.com/2020/04/08/sports/germanysoccer-coronavirus.html (accessed on 20 August 2020).

10. VanOpdorp. Bundesliga: Angela Merkel Rules Out Fans in Stadiums for Now-Reports. Available online: https: / /www.dw. $\mathrm{com} / \mathrm{en} /$ bundesliga-angela-merkel-rules-out-fans-in-stadiums-for-now-reports/a-54600649 (accessed on 17 August 2020).

11. Barker. Ligue 1 Starts with Concern. Available online: https://sportsfinding.com/ligue-1-starts-with-concern/56097 (accessed on 21 August 2020).

12. Simmons, R. English Football: Why Financial Calamity Facing Clubs Is Even Worse than in Mainland Europe. Available online: https: / theconversation.com/english-football-why-financial-calamity-facing-clubs-is-even-worse-than-in-mainlandeurope-147156?utm_source=linkedin\&utm_medium=bylinelinkedinbutton / (accessed on 18 October 2020).

13. Castro, A.; Carter, H.; Zanetti, M. Potential global impact of the N501Y mutation on MHC-II presentation and immune escape. bioRxiv 2021. [CrossRef]

14. Cunningham, A.C.; Goh, H.P.; Koh, D. Treatment of COVID-19: Old tricks for new challenges. Crit. Care 2020, 24, 91. [CrossRef] [PubMed]

15. Olczak, M.; Reade, J.; Yeo, M. Mass Outdoor Events and the Spread of an Airborne Virus: English Football and Covid-19; Department of Economics, Reading University: Reading, UK, 2020.

16. Alexander, A.; Martin, H.; Lackner, M. Mass Gatherings Contributed to Early COVID-19 Spread: Evidence from US Sports, Working Paper; University of Linz: Linz, Austria, 2020.

17. Martinez, M.W.; Tucker, A.M.; Bloom, O.J.; Green, G.; DiFiori, J.P.; Solomon, G.; Phelan, D.; Kim, J.H.; Meeuwisse, W.; Sills, A.K.; et al. Prevalence of Inflammatory Heart Disease Among Professional Athletes With Prior COVID-19 Infection Who Received Systematic Return-to-Play Cardiac Screening. JAMA Cardiol. 2021. [CrossRef] [PubMed]

18. BBC. Tokyo 2020: Games Organisers See Budget Increase for Delayed. Available online: https://www.bbc.com/sport/olympics/ 55408473 (accessed on 10 April 2021).

19. Wright, D. Foot the Bill: English Teams Face Going Out of Business If Season Not Finished with EFL Worried about Coronavirus Insurance Crisis. Available online: https:/ / www.thesun.co.uk/sport/football/11195778/english-football-threat-coronavirus (accessed on 20 August 2020).

20. Franzke, R. Zwölf Vereine Haben Bereits TV-Geld Abgetreten: 13 der 36 Profiklubs Droht Insolvenz-Noch in Dieser Saison [Twelve Clubs Have Already Given up TV Money: 13 of the 36 Professional Clubs Are Threatened with Bankruptcy-This Season]. Available online: https:/ / www.kicker.de/773385/artikel (accessed on 20 August 2020).

21. Reinefeld, L. Brose zieht sich aus Basketball zurück [Brose Withdraws from Basketball]. Available online: https://www.npcoburg.de/sport/regional/sp_sport/sportnp/Brose-zieht-sich-aus-Basketball-zurueck;art83524,7246571 (accessed on 20 August 2020).

22. Bandyopadhyay, K. Introduction: COVID-19 and the soccer world. Soccer Soc. 2021, 22, 1-7. [CrossRef]

23. Chanavat, N.; Desbordes, M.; Lorgnier, N. Routledge Handbook of Football Marketing; Taylor \& Francis: Abingdon, UK, 2017.

24. Cutler, M. Sponsorship spend to fall \$17.2bn; Financial Services by \$5.7bn. Available online: https: / / twocircles.com/us-en/ articles/projections-sponsorship-spend-to-fall-17-2bn (accessed on 15 November 2020).

25. Simmons, R. Financial foul play? An analysis of UEFA's attempts to restore financial discipline in European football. Available online: https: / voxeu.org/article/own-goal-uefa-s-financial-fair-play-initiative-misguided (accessed on 30 April 2021).

26. Simmons, R.; Frick, B. Pay and performance of players in sports leagues: International comparisons. In The Business of Sports; Praeger Publishers: Westport, CT, USA, 2008; Volume 2.

27. Bryson, A.; Frick, B.; Simmons, R. The returns to scarce talent: Footedness and player remuneration in European soccer. J. Sports Econ. 2013, 14, 606-628. [CrossRef]

28. Franck, E.; Nüesch, S. Talent and/or popularity: What does it take to be a superstar? Econ. Inq. 2012, 50, 202-216. [CrossRef]

29. Frick, B. Performance, salaries, and contract length: Empirical evidence from German soccer. Int. J. Sport Financ. $2011,6,87$.

30. Frick, B. Salary determination and the pay-performance relationship in professional soccer: Evidence from Germany. In Sports Economics After Fifty Years: Essays in Honour of Simon Rottenberg. Oviedo: Ediciones de la Universidad de Oviedo; Universidad de Oviedo: Ovideo, Spain, 2006; pp. 125-146.

31. Frick, B. The Football Players' Labor Market: Empirical Evidence from the Major European Leagues. Scott. J. Political Econ. 2007, 54, 422-446. [CrossRef] 
32. Thrane, C. Performance and actual pay in Norwegian soccer. J. Sports Econ. 2019, 20, 1051-1065. [CrossRef]

33. Deutscher, C. Determining the drivers of player valuation and compensation in professional sport: Traditional economic approaches and emerging advances. In Personnel Economics in Sports; Edward Elgar Publishing: Cheltenham, UK, 2018.

34. Adler, M. Stardom and talent. Am. Econ. Rev. 1985, 75, 208-212.

35. Rosen, S. The economics of superstars. Am. Econ. Rev. 1981, 71, 845-858.

36. KEA. The Economic and Legal Aspects of Transfers of Players. Available online: https://ec.europa.eu/assets/eac/sport/library/ documents / cons-study-transfers-final-rpt.pdf (accessed on 12 May 2020).

37. Simmons, R. Overpaid athletes? Comparing american and european football. Work. USA 2007, 10, 457-471. [CrossRef]

38. de Dios Crespo Pérez, J. Employment Relationships at National Level: Spain. In Regulating Employment Relationships in Professional Football: A Comparative Analysis; Sports Law and Policy Centre: Nocera Inferiore, Italy, 2014.

39. Müller, O.; Simons, A.; Weinmann, M. Beyond crowd judgments: Data-driven estimation of market value in association football. Eur. J. Oper. Res. 2017, 263, 611-624. [CrossRef]

40. Kirschstein, T.; Liebscher, S. Assessing the market values of soccer players-a robust analysis of data from German 1. and 2. Bundesliga. J. Appl. Stat. 2019, 46, 1336-1349. [CrossRef]

41. Herm, S.; Callsen-Bracker, H.-M.; Kreis, H. When the crowd evaluates soccer players' market values: Accuracy and evaluation attributes of an online community. Sport Manag. Rev. 2014, 17, 484-492. [CrossRef]

42. Sánchez-Fernández, R.; Iniesta-Bonillo, M.Á.; Holbrook, M.B. The conceptualisation and measurement of consumer value in services. Int. J. Mark. Res. 2009, 51, 1-17. [CrossRef]

43. Damodaran, A. The Dark Side of Valuation: Valuing Young, Distressed, and Complex Businesses; Ft Press: Upper Saddle River, NJ, USA, 2009.

44. Damodaran, A. Price and Value: Discerning the Difference; New York University: New York, NY, USA, 2014.

45. Dixon, E. Report: Broadcasters predict TV rights value decline post Covid-19. Available online: https://www.sportspromedia. $\mathrm{com} /$ news/tv-rights-value-decline-premier-league-coronavirus (accessed on 28 August 2020).

46. Whitney, J.D. Bidding till bankrupt destructive competition in professional team sports. Econ. Inq. 1993, 31, 100-115. [CrossRef]

47. Szymanski, S. The economic design of sporting contests. J. Econ. Lit. 2003, 41, 1137-1187. [CrossRef]

48. Dietl, H.M.; Franck, E.P.; Grossmann, M.; Lang, M. Contest Theory and Its Applications in Sports; University of Zurich Institute for Strategy and Business Economics Working Paper; University of Zurich: Zurich, Switzerland, 2009.

49. Dietl, H.M.; Franck, E.; Lang, M. Overinvestment in team sports leagues: A contest theory model. Scott. J. Political Econ. 2008, 55, 353-368. [CrossRef]

50. Frick, B.; Prinz, J. Crisis? What crisis? Football in Germany. J. Sports Econ. 2006, 7, 60-75. [CrossRef]

51. Dietl, H.; Frick, B. Introduction to Symposium on Sports Economics. East. Econ. J. 2007, 33, 376-377. [CrossRef]

52. Gerrard, B. Competitive balance and the sports media rights market: What are the real issues? In Proceedings of the IASE Conference, Neuchâtel, Switzerland, 23-24 May 2003.

53. Franck, E. Private firm, public corporation or member's association-Governance structures in European football. Int. J. Sport Financ. 2010, 5, 108-127.

54. Buraimo, B.; Frick, B.; Hickfang, M.; Simmons, R. The economics of long-term contracts in the footballers' labour market. Scott. J. Political Econ. 2015, 62, 8-24. [CrossRef]

55. Ames, N. Arsenal Announce Squad Pay-Cut but Deal Not Sealed with Some Players. Available online: https://www.theguardian. com/football/2020/apr/20/arsenal-announce-squad-pay-cut-but-deal-not-sealed-with-some-players (accessed on 14 March 2021).

56. Harris, R. Premier League Stars Face Backlash over Pay during Pandemic. Available online: https://abcnews.go.com/Sports/ wireStory/ premier-league-stars-face-backlash-pay-pandemic-69945036 (accessed on 20 August 2020).

57. CIES. CIES Football Observatory Weekly Post Contract Policy: Spanish Giants Head the Table. Available online: https://footballobservatory.com/IMG/sites/b5wp/2017/222/en (accessed on 20 August 2020).

58. Dietl, H.; Fort, R.; Lang, M. International sport league comparisons. In Routledge Handbook of Sport Management; Robinson, L.P., Chelladurai, P.G., Bodet, G., Eds.; Routledge: Oxford, UK, 2013; pp. 388-404.

59. MacInnes, P. Uefa's Aleksander Ceferin Talked about a Salary Cap-But Could It Ever Happen? Available online: https: / / www.theguardian.com/football/2017/jul/09/uefa-ceferin-smaller-leagues-talk-wage-cap (accessed on 10 February 2021).

60. Bundestag, D. Möglichkeit von Gehaltsobergrenzen im Fußball für Spieler und Berater sowie der Deckelung von Ablösesummen [Possibility of Salary Caps in Football for Players and Consultants as Well as Capping Transfer Fees]. Available online: https: //www.bundestag.de/resource/blob/707918/dd648d95bc3f3a0f092e289243ad3ae7/WD-10-031-20-pdf-data.pdf (accessed on 18 October 2020).

61. Rumsby, B. Aleksander Ceferin: Uefa Considering Post-Coronavirus Salary cap. Available online: https://www.telegraph.co.uk/ football/2020/05/20/aleksander-ceferin-uefa-considering-post-coronavirus-salary (accessed on 20 August 2020).

62. BBC. League One \& Two Clubs Vote to Introduce Salary Cap. Available online: https://www.bbc.com/sport/football/53696424 (accessed on 20 August 2020).

63. Fischer, B. League One and League Two Salary Cap Scrapped after Appeal by Players' Union. Available online: https://www. theguardian.com/football/2021/feb/09/league-one-two-scrap-salary-cap-after-appeal-by-players-union-pfa (accessed on 10 April 2021). 
64. Dietl, H.M.; Duschl, T.; Lang, M. Executive pay regulation: What regulators, shareholders, and managers can learn from major sports leagues. Bus. Politics 2011, 13, 1-30. [CrossRef]

65. Khosravi, F.; Jha-Thakur, U. Managing uncertainties through scenario analysis in strategic environmental assessment. J. Environ. Plan. Manag. 2019, 62, 979-1000. [CrossRef]

66. Cardenas, I.C.; Halman, J.I. Coping with uncertainty in environmental impact assessments: Open techniques. Environ. Impact Assess. Rev. 2016, 60, 24-39. [CrossRef]

67. Tapinos, E. Perceived environmental uncertainty in scenario planning. Futures 2012, 44, 338-345. [CrossRef]

68. van Vuuren, D.P.; Riahi, K.; Moss, R.; Edmonds, J.; Thomson, A.; Nakicenovic, N.; Kram, T.; Berkhout, F.; Swart, R.; Janetos, A.; et al. A proposal for a new scenario framework to support research and assessment in different climate research communities. Glob. Environ. Chang. 2012, 22, 21-35. [CrossRef] 